\title{
Usoda maja '68 in (post)socializem: literatura med revolucijo in tranzicijo
}

\author{
Marko Juvan
}

ZRC SAZU, Inštitut za slovensko literaturo in literarne vede, Novi trg 2, 1000 Ljubljana https://orcid.org/0000-0001-5326-7276

marko.juvan@zrc-sazu.si

\begin{abstract}
Članek na podlagi pojmovanja, da je za modernizem odlocilna "predstavna bližina družbene revolucije" (Anderson) vperspektivi teorije svetovnih-sistemov obravnava neoavantgardistično radikalizacijo modernizma $v$ šestdesetih in sedemdesetih letih 20. stoletja. Pri tem se osredotoča na literarno in teoretsko polje kapitalistične Francije v primerjavi s pospešenim razvojem obeh področijv socialistični periferiji svetovnega modernizma - v neuvrščeni in samoupravni Jugoslaviji. Interpretira povezovanje eksperimentalne literature in (post) strukturalistične teorije v Sloveniji „dolgega leta 1968 « od prvotnega zavezništva neoavantgardnega tipa do razkola sredi sedemdesetih let. V sklepu nakaže divergentne interpretacije zgodovinskega procesa med poskusom študentske revolucije 1968 in letom 1989, ko globalizirani kapitalizem prevlada socializem, modernizem pa preide v postmodernizem.
\end{abstract}

Ključne besede: literatura in družba / študentsko gibanje / revolucija / socializem / modernizem / neoavantgarda / svetovni sistem / slovenska književnost

\section{8: poskus svetovne revolucije}

Da je bilo študentsko gibanje $\mathrm{v}$ šestdesetih in sedemdesetih letih 20 . stoletja heterogeno, se zdi samoumevno, saj je bila njegov nosilec generacija, še neutirjena v distribucijo vlog odraslosti; tvorile so ga samonikle politike in, čeprav je bilo globalno, so ga določale različne lokalne razmere in ideologije. ${ }^{1}$ Kljub raznorodnosti pa je poleg povezujoče hedonistično-uporniške mladinske kontrakulture (rocka, jeansa, dolgih las, seksualne revolucije itn.) moč razpoznati univerzalno politično težnjo

\footnotetext{
${ }^{1}$ Članek je rezultat projekta "Maj $68 \mathrm{v}$ literaturi in teoriji: zadnja sezona modernizma v Franciji, Sloveniji in svetu“ (J6-9384), ki ga financira Javna agencija za raziskovalno dejavnost Republike Slovenije. - Posamezni segmenti se opirajo na dva avtorjeva novejša prispevka v angleščini (Juvan, »Literature«, »Peripheral«).
} 
gibanja - emancipacijski upor obstoječemu v rezultanti anarhizma, socializma, antiimperializma in liberalizma. V svetu hladne vojne so osvobodilne silnice prečile meje med vzhodnim in zahodnim blokom, a sta jih antagonistični polji različno konfigurirali. Poenostavljeno rečeno: liberalnodemokratični kapitalistični Zahod je izzval upor prek izrazitejšega socializma ( $v$ imenu odprave socialnih razlik), enostrankarski socialistični Vzhod pa je zbujal odziv z izrazitejšim liberalizmom (kot zagovorom individualnih svoboščin).

Danes razširjena kritika, ki socializmu očita totalitarizem, se je uveljavljala prav v letih, ko je anglo-ameriškemu jedru svetovnega-sistema z neoliberalizmom uspelo nevtralizirati revolucionarni naboj pravkar minulega študentsko-delavskega upora. To je jedro doseglo tudi na tranzicijskih periferijah in jih $\mathrm{z}$ globalizmom postopno kooptiralo. Zato se je ob presoji konsenza o totalitarizmu treba zavedati svetovnozgodovinskih okoliščin socializma. Po oktobrski revoluciji, ki je z nasiljem organiziranih množic nad nosilci politično-ekonomske premoči Rusiji omogočila preskok iz fevdalno-agrarne v socialistično industrijsko državo, je novi družbeni red moral preživeti v spopadu s starejšim, razvitejšim, prožnejšim in imperialnim svetovnim-sistemom. ${ }^{2}$ Socializem rusko-sovjetskega tipa, imenovan realni, si je v tekmi z gospodarsko močnejšim blokom pozicije utrjeval $s$ socialnimi politikami v prid delavskih množic, z industrializacijo, vojsko, ideološkimi aparati in mednarodnimi zavezništvi, obenem pa z zatiranjem vsega, kar bi v njem lahko bilo nastavek konkurenčnega svetovnega-sistema. Prav to sistemsko discipliniranje družbe je realni socializem vodilo $\mathrm{v}$ okostenelost in propad, medtem ko so njegove socialne politike, privlačne tudi za delavski razred Zahoda, kapitalizem po drugi svetovni vojni silile $\mathrm{k}$ omilitvi delovanja tržne logike, tj. $\mathrm{k}$ državi blaginje.

Po prelomu s sovjetskim Informbirojem leta 1948 se je socialistična Jugoslavija morala na novo umestiti med oba bloka. ${ }^{3}$ Titovi komunisti so našli rešitev. Prvič, posegli so v bipolarno strukturo sveta. $S$ soustanoviteljsko vlogo pri gibanju neuvrščenih - prvi kongres je imelo v Beogradu leta 1961 - so med kapitalistični prvi svet in realsocialistični drugi svet umestili tretji svet, zvečine postkolonialen in politično heterogen. Kot evropska država, umeščena v srednjeevropsko "vmesno

${ }^{2}$ Kapitalizem se je brez večjih težav prilagajal absolutizmu, liberalni demokraciji, od sredine 20. stoletja naprej fašizmu, nacizmu ter evropskim in latinskoameriškim pučističnim vojaškim režimom, nazadnje pa še t. i. iliberalni demokraciji in desnemu populizmu.

${ }^{3} \mathrm{O}$ širšem zgodovinskem kontekstu in poteku jugoslovanskega študentskega gibanja v šestdesetih in sedemdesetih letih gl. Čepič; Fichter; Gabrič; Kanzleiter; Klasić. 
perifernost " (Tötösy) med Washingtonom in Moskvo, se je Jugoslavija postavila na čelo neuvrščenih. Jugoslovanski model socialistične družbene modernizacije, ki je nekdaj zaostalo deželo industrializiral, urbaniziral, zagotovil vsem javno zdravstvo in šolstvo ter enakopravnost žensk, se je oddaljeval od realsocializma in se v šestdesetih letih 20. stoletja odprl za zahodnjaško modernost. Drugič, v petdesetih letih je bil po zamislih ideologa Edvarda Kardelja uveden sistem neposredne demokracije, imenovan socialistično samoupravljanje. Jugoslovanski eksperiment, ki se je navdihoval pri anarhizmu in utopičnem socializmu, je zbudil mednarodno zanimanje kot alternativa kapitalistični liberalni demokraciji in sovjetskemu državno-planskemu gospodarstvu. Jugoslovansko samoupravljanje, ki naj bi delovalo v vseh družbenih podsistemih, je bilo v praksi omejeno; ostalo je pod popolnim nadzorom Zveze komunistov. Ta recidiv realsocialističnega vzorca je bil prvi razlog, da je tudi jugoslovanska verzija socializma zašla $\mathrm{v}$ krizo in katastrofo. Drugi vzrok je bil v svetovnem-sistemu. Zahodna posojila, ki so Jugoslavijo kot tamponsko državo strateško podpirala po njenem konfliktu z Varšavskim paktom, so jo prisilila v odvisnost od globalnega kapitalizma in jo dolžniško izčrpavala, posebej po Titovi smrti. Tretji vzrok je "socialistična tržna ekonomija«, ki jo je po 1965 vpeljala mlajša, liberalna struja Zveze komunistov Jugoslavije (prim. Fichter 103; Kanzleiter 220; Klasić 30-50). Izkazala se je za infiltracijo svetovnega-sistema, ki je $\mathrm{v}$ načelno egalitarnem socializmu proizvedel hudo neenakost, $s$ tem pa okrepil razredne in mednacionalne konflikte.

Pariški maj 1968 je ikona študentsko-delavskega upora, policentričnega poskusa svetovne revolucije $\mathrm{v}$ šestdesetih in zgodnjih sedemdesetih letih 20. stoletja. V tem »dolgem letu '68" (Vinen) so bili ideali vstaj socialna pravičnost, svoboda, neposredna demokracija, mednarodni mir, rasna, etnična in družbenospolna enakopravnost, konec imperializma in uveljavitev mladih kot subjekta $\mathrm{v}$ sporu s starejšo generacijo, dojeto kot nosilko obstoječega. $\mathrm{Na}$ vrhuncu hladne vojne je gibanje študentov na obeh straneh železne zavese vpeljalo tip uporniškega agensa - t. i. multitudo (Hardt in Negri). ${ }^{4}$ Mnoštvo posameznikov na izteku adolescence se je samoorganiziralo v mednarodno omrežje raznorodnih skupin in frakcij, ki pa so se skupno in zunaj institucionalizirane stare levice borile za transformacijo obeh antagonističnih sistemov, kapitalističnega in socialističnega. Kot je razvidno

${ }^{4}$ Pomensko odprti, utopično anarhični pojem multitude je alternativa tradicionalnih revolucionarnih konceptov ljudstva, množice in razreda. Na sledi Spinoze sta ga Negri in Hardt oblikovala ob izkušnji protisistemskih gibanj 20. in 21. stoletja. 
iz zbornika Voices of 1968 (Mohandesi idr., „What was 1968«), so se študentke in študenti od Mehike prek Severne Amerike in Evrope do Japonske z uličnimi demonstracijami in zasedbami fakultet solidarno uprli imperializmu (vojni ZDA proti Vietnamu in invaziji Sovjetske zveze na Češkoslovaško), predvsem pa sistemskemu nasilju, ki jim je onemogočalo vzeti usodo v svoje roke. V izumljanju emancipacijskih idej so mladi prehajali od političnega aktivizma v hedonizem - v uporu patriarhalni družini in tradicionalni morali so eksperimentirali s hipijevskim življenjem v komuni, s sproščeno spolnostjo in z drogami, zasmehovali so srednjeslojsko potrošništvo in akademizem, obenem pa uživali v kontrakulturi. ${ }^{5}$

Študentska multituda je na kapitalističnem Zahodu (ZDA, Nemčija, Francija, Velika Britanija, Italija) protestirala proti okostenelosti univerze. Od sredine šestdesetih se je bojevala proti policijskemu nasilju in konservativni, avtoritarni oblasti. Nasprotovala je imperializmu, rasizmu, patriarhatu in homofobiji. Posebej v Franciji in Italiji se je skupaj s stavkajočim delavstvom uprla socialni neenakosti in izkoriščanju. Njihovi vrstniki na socialističnem Vzhodu (Madžarskem, Poljskem in Češkoslovaškem) so proti univerzitetni instituciji, ki je zamujala $\mathrm{z}$ modernizacijo, protestirali že od sredine petdesetih let. Čehi so v stikih z nemškimi kolegi spoznali, da so njihovi problemi in cilji različni, kar velja tudi za Poljsko in Madžarsko. Vzhodnjaki so vstali proti skromnemu življenjskemu standardu v centralno vodenem gospodarstvu, proti komunistični nomenklaturi in birokraciji, zatiranju svobode govora ter sovjetski hegemoniji. Delavstvo jih je ponekod s stavkami in delavskimi sveti podpiralo, je pa komunistična oblast proletariat tudi izrabljala za podporo pri zatiranju študentov in kritičnih intelektualcev. Današnje interpretacije izpostavljajo prozahodnost študentskih protestov na Vzhodu, zamolčijo pa socialno-liberalno usmeritev, kakor tudi posamezne nacionalistične in populistične težnje.

Svetovna študentska revolta je vzvalovala tudi neuvrščeno Jugoslavijo, s Socialistično republiko Slovenijo vred. ${ }^{6}$ Kritika imperializma ZDA in ZSSR je bila v Jugoslaviji - tamponski coni med Vzhodom in Zahodom - sicer tudi na liniji Zveze komunistov Jugoslavije, stranke

${ }^{5}$ Kontrakultura je že sama težila v politično protestništvo, a tudi kadar ni, se je $s$ svojimi antiavtoritarnimi in participatornimi vrednotami vsaj ujemala s študentskim gibanjem (Fichter 106).

${ }^{6}$ Madigan Fichter, ki podobno kot Kanzleiter poudari mednarodnost jugoslovanskega študentskega gibanja, opozarja, da so se v Jugoslaviji protesti mladih pojavljali že od konca petdesetih let, torej ne gre preprosto za posnemanje pariškega maja '68 (Fichter 102). 
oblasti. Tako so se študentsko-delavski protesti proti birokraciji, tehnokraciji in nezadostnem uresničenju samoupravljanja lahko sklicevali na uradno ideologijo, ki je jugoslovanski družbenogospodarski sistem predstavljala kot tretjo pot med prvim in drugim svetom.

Proti koncu šestdesetih let se je v slovenski komunistični politiki podobno kot na Čehoslovaškem v praški pomladi leta 1968 - začasno utrdila reformistična struja t. i. liberalizma, ki je po 1965 vpeljevala elemente zahodnega tržnega gospodarstva in sproščala ideološke omejitve. $\mathrm{V}$ tem edinstvenem zgodovinskem spletu okoliš̌čn se je v socialistični in neuvrščeni Jugoslaviji modernizacija kapitalističnega Zahoda prekrižala z modernizacijo socialističnega Vzhoda, kar je tudi na Slovenskem zaostrilo protislovja: ${ }^{7}$ samoupravljanje se je na eni strani $s$ t. i. tehnokracijo približalo menedžerstvu zahodnega tipa, pa tudi potrošništvu zahodnega srednjega sloja, medtem ko so se razkrile dramatične socialne neenakosti, podobne razredni razslojenosti kapitalizma.

$\mathrm{V}$ liberalni konjunkturi je tudi slovenska študentska populacija lahko odkrito izrazila svoje nezadovoljstvo, čeprav jo je oblast nadzorovala in poskušala usmerjati prek univerzitetnih organov Zveze komunistov, študentske demonstracije pa krotiti s policijsko silo; oblast je eksemplarično kaznovala verbalne prestopke zoper socialistične norme in zaplenila nekaj številk študentskega časopisa. To nasilje je še podžgalo konfrontacije z oblastjo (Fichter 105). Študentke in študenti, pripadajoči številčni povojni (baby boom) generaciji, so protestirali proti vojaškim agresijam obeh velesil (na Vietnam in Češkoslovaško), zbirokratiziranemu političnemu vodstvu, socialnim razlikam med »rdečo buržoazijo in delavstvom, slabim življenjskim razmeram mladih in njihovi brezposelnosti, oteženem dostopu revnejših do študija ter nezadostnem financiranju univerze in njeni rigidnosti. Študentski protestniki v Sloveniji, ki so bili $s$ kolegi v drugih republikah povezani v izrazito "vsejugoslovanski« protest (prim. Fichter 115), so se v kritiki deformacij jugoslovanskega socializma sklicevali na izvorne ideale socialistične revolucije, ki naj bi jih starejša generacija izdala, in pozivali k popolni uresničitvi samoupravljanja, začenši z možnostjo soudeležbe pri upravljanju univerze in družbe nasploh. Po drugi strani pa so študentje zahtevali več liberalnih svoboščin in hedonizma zahodnjaškega tipa.

Študirajoči, ki so se v Beogradu, Ljubljani, Sarajevu in Zagrebu pridružili mednarodnemu gibanju, se povezovali z njegovimi akterji in ga v svojih glasilih solidarno spremljali, so v dolgem letu 1968 privzeli

${ }^{7} \mathrm{~V}$ tem obdobju so naraščale tudi razlike med severnimi in južnimi jugoslovanskimi republikami, posledične napetosti med njimi pa so podžigale nacionalizme. 
samoorganizirane protestne prakse zahodne multitude, kot so akcijski odbori, demonstracije, stavke, transparenti, alternativna predavanja ter zasedbe fakultet in ad hoc preimenovanja univerz (npr. "Rdeča univerza Karla Marxa « veogradu). Podobno kakor Jean-Paul Sartre in drugi levičarski intelektualci, ki so v Franciji podprli študentsko-delavski upor proti konservativnemu golizmu, so v Jugoslaviji ravnali tudi vidni univerzitetni profesorji in intelektualci revije Praxis. ${ }^{8}$ Tudi ti so obstoječi sistem kritizirali iz perspektiv mladega Marxa, nove levice in eksistencializma. Medtem ko so se zahteve mladih v kapitalističnih deželah stopnjevale do revolucionarne zamenjave sistema, so v Jugoslaviji študenti zvečine pričakovali reforme, ki bi dosledno uresničile ideale samoupravnega socializma (prim. Kanzleiter 219). Najradikalnejši del študentskih protestnikov je torej jugoslovansko uradno ideologijo vzel zares, namesto da bi vztrajal v cinični distanci do nje. ${ }^{9}$ Prav ta doslednost, ki se je nagibala $\mathrm{k}$ ideji permanentne revolucije pod vodstvom mednarodno povezane multitude, je vznemirila komunistično oblast.

Revolucionarni potencial študentsko-delavske množice je vrgel iz tira uveljavljene leve stranke tudi na Zahodu, saj je postavil pod vprašaj inertnost njihovih konceptov in strategij parlamentarnega ali sindikalnega delovanja. Prestrašil je celo vladajoče. Tako se je general Charles De Gaulle, predsednik Francije, 29. maja 1968 umaknil iz nemirne države (Ross 58-60; Vinen 152-159). V Baden Badnu je na skrivnem sestanku od vrhovnega poveljnika francoske armade dobil zagotovilo, da je vojska pripravljena intervenirati proti študentom. Samozavestnejši zaradi vojaške podpore je bil De Gaulle po vrnitvi v Pariz študentom in delavcem do neke mere pripravljen popustiti pri zahtevah po soudeležbi pri odločanju na univerzi, v družbi in podjetjih, a zgolj v okvirih reforme, ne pa revolucije. Emblem tega odziva je njegova slovita izjava: "La réforme oui, la chienlit, non!« (»Reforma da, karneval/kaos [dobesedno 'sranje v posteljo'] pa ne!«; Ross 65).

Presenetljivo enaka je bila istega leta retorika establišmenta $\mathrm{v}$ sicer antagonističnem družbenogospodarskem sistemu. Kaitlyn Tucker Sorenson je nedavno odkrila, da je France Hočevar, podpredsednik slovenskega Izvršnega sveta, na študentske proteste v Beogradu in Ljubljani v pogovoru s študenti 3. junija 1968 odgovoril z besedami, ki so kakor De Gaullove: "Spremembe da, cirkus ne!«. Znamenitejša je postala sorodna eksklamacija »Demokracija da - razkroj ne!« (Delo, 8. 11. 1968)

${ }^{8}$ Krog revije Praxis je na svojo korčulsko poletno šolo (1964-1974) povabil mdr. Herberta Marcuseja, Ericha Fromma, Leszka Kolakowskega in Ágnes Heller.

${ }^{9} \mathrm{O}$ ideologiji in cinizmu gl. Žižek. 
iz polemike starejšega rodu kulturnikov z neoavantgardnimi objavami mladih v Tribuni in Katalogu ter njihovo razpuščeno igro s tradicijo, izzivalnim ikonoklazmom in literarno-jezikovnim eksperimentiranjem (prim. Dolgan 171-186). To degaullovsko geslo je v imenu socialističnega humanizma, spoštovanja NOB in realistične poetike napadlo literarne tekste, ki so prevratnega leta v Ljubljani na način "radikalne igrivosti $\aleph^{10}$ vibrirali z dogodkom mednarodne študentske vstaje.

Ko je maršal Tito, voditelj SFRJ, junija '68 študentom na videz spravljivo prisluhnil, jim izrazil pripravljenost na reforme, je to storil v paternalistični drži, podobni De Gaullovi. Potem ko je na tajni seji CK $\mathrm{ZKJ}$ dal smernice za zatrtje demonstracij in pregon izpostavljenih kritičnih intelektualcev in študentov, ${ }^{11}$ je 9 . junija 1968 nastopil na televiziji, priznal napake oblasti, dal študentskim zahtevam do neke mere prav, zaključil pa je s pozivom, naj se študentje $\mathrm{z}$ ulic vrnejo $\mathrm{k}$ izpitom. In študenti so ga tistega leta večinsko še poslušali. Zveza komunistov je $\mathrm{v}$ naslednjih letih eksplozivnost protestov umirila $s$ kombinacijo kooptacije avtonomnih študentskih politik, koncesij njihovim zahtevam in kaznovanja tistih posameznikov in kolektivov, ki jih je imela za sovražne (Fichter 118).

\section{Imaginacija revolucije, modernizem in neoavantgarda $v$ jedrnih državah}

Od Kopernikovega heliocentričnega modela (De revolutionibus orbium coelestium, 1543), ki je pretrgal $\mathrm{z}$ antično-srednjeveškimi predstavami o stvarstvu, prek angleške »slavne revolucije» (1688-1689), ki je s parlamentom omejila suverenost monarha, do francoske meščanske revolucije 1789, ki je "stari režim" preoblikovala v republiko po meri meščanskih idej o enakopravnih in svobodnih državljanih, in ruske proletarske revolucije 1917, v kateri so komunisti vpeljali socializem kot alternativo kapitalizmu, se revolucija izkazuje za bistvo modernosti, pa naj jo razumemo kot idejo, koncept ali dogodek. Čeprav zgodovina ne

${ }^{10}$ Tucker Sorenson interpretira pejorativno metaforo "cirkusa« kot teoretski ključ do karnevalske logike »radikalne igrivosti«, ki je zaznamovala slovensko alternativno kulturo od 1968 do panka osemdesetih let.

${ }^{11}$ Represivna kampanja proti protagonistom gibanja, njihovim profesorskim podpornikom in kritičnim levičarjem revije Praxis se je stopnjevala med 1972 in 1975 (prim. Kanzleiter 224). Pri tem je oblast uporabljala stalinistične opozicije med t. i. poštenimi študenti in vrinjenci zunanjih sovražnikov - od CIA prek reakcionarnih sil do maoistov (Fichter 112). 
pozna hipnih sprememb, ki bi zajele vsa področja bivanja in prekinila dolgo trajanje družbenih struktur in mentalitet, pojem revolucije implicira prav to. Je rez, ki razpre čisto sedanjost, ko se poruši stari red, novi pa se iz zamišljenih ciljev in namer šele nakazuje v mnogoterih možnih udejanjenjih. Ni ga dogodka ali ideje, ki bi tako kot revolucija izpostavila sedanjost kot odprto, kaotično, a obenem usmerjeno $\mathrm{v}$ prihodnost. Zato je revolucija v osrčju predstave o modernosti, pa tudi ideje modernizma.

Susan Stanford Friedman je v duhu postkolonialne etike predlagala priredno, policentrično, a obenem nadzgodovinsko koncepcijo modernosti in modernizma (Friedman, Planetary Modernisms). Modernost ima za ponovljivo konstelacijo, ki jo odlikujejo občutek sedanjosti kot nečesa novega in mnogoterega, prelom $s$ preteklim, pospešene menjave (»vrtinec sprememb«), intenzivni stiki, mešanje kultur in družbene delitve. Tako opredeljena modernost naj bi se pluralno uresničevala od starega veka do sedanjosti, od Daljnega vzhoda do Zahoda. Pluralen, policentričen in ponovljiv je po Friedman tudi modernizem, samorefleksivna in "estetska dimenzija sleherne modernosti« (x). Njena tipologija ponovljive modernosti in pluralnih modernizmov demontira primat novoveškega Zahoda. Čeprav fenomenološko ustrezno opredeli oba pojma, zanika njuno historičnost.

Namesto tovrstnih poskusov, ki s pluralizacijo zgodovinski koncept modernizma spreminjajo $\mathrm{v}$ metaforo, se je treba lotiti analize razmer, $\mathrm{v}$ katerih je Zahod svojo idejo modernosti sploh lahko uveljavil v svetu tako, da je z njo epohalno definiral sam svet. Kot poudarjajo Anthony Giddens (Consequences 1, 174-178), Fredric Jameson (Singular 17-95) in celo Friedman (Planetary 121), je samozavedanje o prelomu s tradicijo ter pospešenih spremembah in inovacijah prišlo do svojega pojma najprej na Zahodu. S tem je Zahod legitimiral svojo hegemonijo v svetovnem-sistemu. Znano je, da je tudi izraz modernizem izvorno evropski (prim. Škulj). Sprva je v nemško govorečih deželah sproti označeval umetnost fin-de-siècla, pozneje pa je poimenoval umetniški tok med 1880 in 1930. Tvorila naj bi ga dela, ki so poetološke inovacije pri ubesedovanju ambivalentne izkušnje destabilizirajoče modernosti zamejila $\mathrm{v}$ singularno estetsko formo in perspektivo. Takšno pojmovanje modernizma se je $\mathrm{v}$ literarni vedi utrdilo šele $\mathrm{v}$ zgodovinski retrospekciji, in to prav v šestdesetih letih 20. stoletja.

Po Jamesonu (171-180) in Perryju Andersonu (104-105) modernizem z začetka 20. stoletja odlikuje odpor do umetniškega akademizma meščanske dobe in do sodobnega poblagovljenja kulture; za Andersona je ključna še predstavna bližina revolucije, kakršna je bila oktobrska 
v Rusiji. Komodifikacija umetniške produkcije je po 1900 narasla, že tako pogojno estetsko avtonomijo visoke umetnosti pa je ogrozila množična kultura. Po Jamesonu si je visoka umetnost z refleksivno usmeritvijo v raziskavo literarnega jezika in subjekta prizadevala utemeljiti svoj pomen $\mathrm{v}$ razmerju do popularne kulture ter tako $\mathrm{v}$ drugi polovici stoletja razvila ideologijo modernizma (Jameson $171-180) .{ }^{12}$ Nasledek tega je tudi uveljavitev obdobnega termina »modernizem». Kot sledi iz Jamesona in Andersona, naj bi se po drugi svetovni vojni v zahodnih državah - potem ko jih revolucija ni več vznemirjala, pa tudi meščanski akademizem je izgubljal prestiž - nekdaj uporni modernizem tudi sam spremenil v blago in se akademiziral, medtem ko se je na obrobjih, celo $\mathrm{v}$ postkolonialnem tretjem svetu, izgubil $\mathrm{v}$ zapoznelem posnemanju. Vendar pa se je modernizem $v$ šestdesetih letih prav zaradi bližine možnosti globalne revolucionarne spremembe sveta prebil iz estetske sfere ter se povezal $s$ kritično teorijo in uporniškimi politikami, da bi prek preobrazbe umetnostne ustanove posegel v preobrazbo obstoječih družbenih razmerij.

Šestdeseta leta so torej obdobje, ko se je na eni strani uveljavila ideologija modernizma kot smeri visoke umetnosti. Pojem modernizem je v stroki prispeval k njegovi akademizaciji; tako opredeljeni tok je postal predmet preučevanja, zbiranja, investicij in kanonizacije. Toda šestdeseta so $s$ študentskim gibanjem - zaradi svojega upora proti svetovnemu sistemu po Immanuelu Wallersteinu (»Antisystemic Movements« 164) zadnje svetovne revolucije - ustvarila ozračje, v katerem se je akademizirani modernizem vendarle prenovil. Konceptualno in politično se je modernizem radikaliziral $\mathrm{v}$ neoavantgardah in eksperimentalni umetnosti. Izraz "eksperimentalna literatura" (prim. Bray idr.) se v nasprotju z vojaško-političnimi (in revolucionarnimi) prizvoki pojma avantgarda spogleduje z znanostjo, kar se sklada s poudarjeno konceptualistično držo neoavantgard. Eksperiment v umetnosti ustreza eksperimentu s samoniklimi oblikami političnega boja študentsko-delavske multitude. Neoavantgardna eksperimentalna literatura je raziskovala literarnost, jezik, medije in družbene pogoje umetnosti, medtem ko se je avantgardnost t. i. teorije, ki je sočasno pognala iz postfenomenološke in marksistične filozofije, križala s scientizmom strukturalne lingvistike in psihoanalize. Teorija je po razlagi Jeana-Michela Rabatéja modernizirala kritični um, da bi nadomestila filozofijo in dekonstru-

${ }^{12}$ Podobno tudi Perry Anderson ugotavlja, da sta se ob upadu modernistične umetnosti »rodila ideologija in kult modernizma. Sama koncepcija se je komaj začela širiti šele v petdesetih letih» (108). 
irala ideologijo (Rabaté 24-91). Predstavna bližina revolucije se je tedaj odražala v literarnih in teoretskih predstavah, da pot do revolucije vodi prek revolucije $\mathrm{v}$ umetnosti oziroma pisanju takšne literature, ki zapusti tradicionalno ustanovo umetnosti ter kot materialna praksa poseže $\mathrm{v}$ družbena razmerja moči.

Še do šestdesetih let je bilo središče "svetovne literarne republike« Pariz (prim. Casanova). V tej metropoli modernizma je bil tudi sedež Situacionistične internacionale (1957-1972), značilno mednarodne umetniško-teoretske neoavantgarde, ki je $\mathrm{v}$ navezavi na Sartra in marksistično misel prebila inertnost visokega modernizma (gl. Hecken in Grzenia). Drugače od zgodovinske avantgarde so takšne neoavantgarde eksperimentalno ustvarjanje nadgradile $s$ teorijo umetniškega polja in njegovega okolja (prim. Foster 20). Situacionisti so hoteli sprevrniti kapitalistično reglementacijo življenja, predvsem členitev na delovni in prosti čas, namenjen pasivnemu potrošništvu. $S$ svojimi subverzivnimi posegi v diskurz (détournement kot parodično-kritična sprevrnitev znakov vladajoče ideologije) in "psihogeografijo" (dérive kot odklon od sistemsko določenega prostora delovanja in vzorcev obnašanja) so razbijali alienativno hierarhijo časovnosti. Prosti čas naj bi postal središče osebne in družbene osvoboditve od logike kapitala, tisto, kar minljivemu bivanju daje neponovljivo kvaliteto. Guy Debord, idejni vodja situacionistov in avtor teoretsko vplivne Družbe spektakla, je že leta 1958 razglasil svoje "Teze o kulturni revoluciji.$^{13} \mathrm{~V}$ njih je Debord modernistični umetnosti zaupal nalogo posega $\mathrm{v}$ stvarnost na način »eksperimentalne konstrukcije vsakdanjega življenja «, ki bo revolucionarno odpravila podrejenost delu kot funkciji kapitala (Debord, "Thèses«; prim. Knabb 53-54).

Deset let pozneje, v revolucionarnem maju '68, je revija Tel Quel natisnila sedem tez o »revoluciji tukaj in zdaj«. V njih je istoimenska neoavantgardna skupina marksizem-leninizem združila s teorijo strukturalizma in literarnim eksperimentom na podlagi konceptov intertekstualnosti in pisanja. Manifest Tel Quela začne izjava: "Akcija, ki se izvaja z nami in prek nas, je ta hip besedilna" (Baudry idr.). Philippe Sollers, vodja skupine, je istega leta $\mathrm{v}$ komunističnem mesečniku Les lettres françaises uveljavljeno estetsko predstavo o književnosti zavrgel kot meščansko in razglasil, da je koncept "pisanja - transformativne alternative leposlovju - skladen s cilji revolucije (citirano v Combes 31-32). Sollers in njegovi leninistični tovariši so hoteli okrepiti vodilni

${ }^{13}$ Ta pojem je na Kitajskem dobil drugačno vsebino; maoizem je sredi študentskega gibanja vplival na Francijo in svet (tudi Slovenijo). 
neoavantgardni status Tel Quela glede na še vedno vplivne nadrealiste in nastajajoče progresivne skupinice. Francoski študentje, ki so demonstrirali in zasedali fakultete, za telquelovce (drugače kot za novo levico) sploh niso bili pravi revolucionarni subjekt, naslednik proletariata; očitali so jim, da »dajejo revolucionarni videz temu, kar je zgolj malomeščanska in levičarska ideološka infiltracija» (Tel Quel, »Mai 1968«).

Sklenemo lahko z Borisom Gobillom, ki v svoji sociologiji francoske literarne avantgarde šestdesetih let trdi, da je vstaja študentov in delavcev povzročila politično krizo, v kateri so modernisti različnih generacij in usmeritev (od nadrealistov in eksistencialistov do materialističnih strukturalistov) izražali prepričanje, da lahko literarno pisanje preoblikuje ne le literarni establišment, pač pa tudi kapitalistično družbo nasploh (Gobille 115-181). Pisatelje, ki so podpirali gibanje, so politični pretresi primorali, da so o vlogi pisateljevanja ponovno razmislili zunaj okvirov literarnega polja in estetske avtonomije $-\mathrm{z}$ vidika revolucije.

\section{Obrobni modernizem v spreminjanju sveta}

Franco Moretti je svetovno literaturo vzporedil z ekonomskim svetovnim-sistemom, konceptom Immanuela Wallersteina. Podobno kot svetovni kapitalizem, razdeljen na gospodujoče jedrne države in podrejene polperiferije in periferije, je tudi svetovna literatura sistem, ki v nasprotju z idealističnimi predstavami ne pozna enakih možnosti vseh za preboj v estetske vrhove. Središča svetovnega sistema literature namreč vseokrog izvažajo oblike in teme, ki so jih ustvarila, prevedla ali predelala, periferije pa to gradivo uvažajo in kombinirajo z lokalnimi repertoarji (Moretti 7-25, 29-40). Medtem ko podobna teorija Pascale Casanova (République) zatrjuje, da so zakonitosti medliterarne konkurence na svetovnem trgu zaradi svojega estetskega reda relativno neodvisne od ekonomije, Moretti vztraja pri analogiji.

Warwick Research Collective - v študijah svetovne književnosti po krivici še na obrobju - je v vztrajne polemike postdekonstrukcionistov in postkolonialistov z Morettijem in Casanovo posegel z materialističnega vidika. Morettijevo analogijo je presegel z relacijo determinacije; svetovna literatura za skupino iz Warwicka ni nič drugega kot »literatura modernega kapitalističnega svetovnega-sistema« (Deckard idr. 15). Raziskovalci ugotavljajo, da je kapitalizem "substrat svetovne literature", medtem ko je modernost njen "predmet in oblika - modernost je tisto, kar svetovna literatura indeksira ali 'o čemer' je in kar daje 
svetovni literaturi njene razlikovalne formalne poteze« (159). To pomeni, da kapitalizem s svojo ekonomijo določa obstoj medijev, institucij in praks, ki globalno diseminirajo repertoar tekstov, izbranih po tržni in/ali estetski vrednosti (slednjo določajo vplivni kritiki, nagrajevalci, sestavljavci kurikulov ipd.).

Literarni svetovni-sistem se tako integrira $\mathrm{v}$ globalizirani kapitalistični proizvodni način. Obenem svetovna književna dela fikcijsko interpretirajo partikularne pojave, ki jih naplavlja Jamesonova »edinstvena modernost (singular modernity) « univerzalnega kapitalizma. $\mathrm{Na}$ podlagi Morettijeve teze o neenakosti v svetovnem literarnem sistemu in Jamesonove ideje edinstvene modernosti warwickovci razložijo razmerje med ekonomskim in estetskim redom $\mathrm{z}$ idejo Leva Trockega o "kombiniranem in neenakomernem razvoju«; v njem gre za "spoj arhaičnih [oblik] s sodobnejšimi oblikami« (Deckard idr. 17). Evolucijska neenakomernost torej ni naključna lastnost literatur, temveč bistvena težnja svetovnega-sistema $\mathrm{v}$ njegovem neomejenem kopičenju presežne vrednosti. Na videz estetska razlika med (sodobno, izvirno in vplivno) literaturo globalnih metropol in književno produkcijo (arhaične, zapoznele in sprejemne) periferije je tako posledica družbeno-politične, ekonomske in institucionalne neenakosti. Z izkoriščanjem obrobja kapitalistična moderna vsiljuje svoje napredne proizvodne načine in odnose manj razvitim ali celo predmodernim družbam. V skladu $s$ tem se estetske oblike iz jedrnih literatur na obrobju kombinirajo $\mathrm{z}$ asinhrono časovnostjo domačih modelov. Iz tega razloga hibridnost perifernega modernizma lahko postane upor proti "zasužnjevanju monokulture» (Deckard idr. 17-22, 49-56).

Georgi Gačev in Dionýz Durišin sta že pred desetletji dokazala, da si literarna gibanja in slogi ne sledijo nujno po "greenwiški« časovnici zahodnega jedra, temveč se pojavljajo tudi hkrati, se razvijajo hitreje ali preskočijo evolucijske stopnje (prim. Ďurišin 43-48, 159-160, 170183). Ta kondenzacija je povzročala sinkretično prepletanje različnih slogov. Z njunega vidika se časovnost perifernih modernizmov izkaže za primer nepravilnega oziroma "pospešenega razvoja«. ${ }^{14}$ To velja tudi za socialistično Slovenijo v letih študentskega gibanja. Prav umestitev jugoslovanske vmesne periferije med dva bloka je v Sloveniji ustvarila politične preplete teorije z eksperimentalno literaturo, ki so se s svojim pospešenim razvojem izkazali za inovativne v svetovnem merilu.

${ }^{14} \mathrm{~S}$ pojmom pospešeni razvoj je Gačev utemeljeval tezo, da je mlada književnost Bolgarije, v novem veku podvržena Otomanskemu cesarstvu, v nekaj desetletjih 19. stoletja preživela celoten razvoj evropske literature in jo dohitela. 
Zapostavljanje socialističnih dežel v preučevanju modernizma se na splošno ujema z usodo, ki jo po Theu D'haenu (»Major Histories») v raziskavah svetovne literature doživljajo manjše evropske književnosti, saj so te potegnile krajši konec od nekdaj prav tako spregledane moderne ustvarjalnosti Afrike ali Daljnega vzhoda. ${ }^{15} \mathrm{~V}$ zadnjem času se položaj izboljšuje, o čemer priča razstava jugoslovanske modernistične arhitekture v Muzeju moderne umetnosti v New Yorku v letih 2018-19 (prim. Stierli idr.). Na njej je bila tudi predstavitev ljubljanskega Trga revolucije (danes Trga republike) Edvarda Ravnikarja. Ta arhitektura dokazuje, da je komunistična partija očitno ovekovečila spomin na revolucijo pod svojim vodstvom prav z modernizmom, in to skoraj sočasno s študentskim gibanjem. Kar Andrei Terian na primeru romunske literature 1960-1980 imenuje »socialistični modernizem«, je bilo ne le v arhitekturi, spomeniški plastiki in slikarstvu, temveč delno tudi v književnosti že vse od konca petdesetih let tudi po volji jugoslovanske oblasti, saj je na ta način navznoter in navzven (mdr. tudi zahodnim gospodarskim partnerjem) dokazovala privrženost modernosti. $\mathrm{V}$ Romuniji je socialistični modernizem pisateljem omogočil zatočišče $\mathrm{v}$ estetski sferi (kar nasprotuje Jamesonovi kritiki esteticizma kot simptoma iztrošenosti modernizma), medtem ko je komunistična oblast podobno kot Zveza komunistov v Jugoslaviji - modernizem uporabila za mit napredka, ki ga je kompromitiral stalinizem (Terian 137). Na splošno so se modernistične ideje in literarne tehnike na Vzhodu začele opazneje uveljavljati po letu 1956 (Neubauer in Cornis-Pope 90-94), po koncu prevlade socrealistične pravovernosti, ki je književni modernizem ožigosala kot dekadenten, malomeščanski ali nihilističen, tuj delovnemu ljudstvu. Modernistični pojavi v socialističnih deželah so se navezovali na predvojne domače zgodovinske avantgarde in moderniste, po drugi strani pa so se napajali iz zahodnega eksistencializma, drame absurda, novega romana in drugih smeri poznega modernizma.

T. i. liberalizem na Slovenskem, vzporeden s praško pomladjo in z romunsko odjugo, je socialistično modernizacijo križal z njeno kapitalistično tekmico, $s$ čimer je ustvaril razmere, $v$ katerih je predstavna bližina svetovne revolucije revolucionirala tudi domačinski modernizem. Ta se je po ugotovitvah Miška Šuvakovića v Jugoslaviji iz "socialističnega esteticizma" petdesetih let tedaj ravno levil v "zmerni modernizem« (25-26). ${ }^{16}$ Modernizem je z vključitvijo mladih piscev in

${ }^{15}$ Zapostavljanju socialističnih verzij modernizma morda botruje predsodek, da je komunizem vsiljeval zgolj socialistični realizem, modernizem pa onemogočil.

${ }^{16}$ Tudi Terian navaja, da v času t. i. liberalizacije v Romuniji okoli leta 1965 modernizem - romunski literaturi je vtisnil pečat zlasti v dvajsetih letih 20. stoletja - 
teoretikov $\mathrm{v}$ študentsko vstajo energično krenil v različne neoavantgardne skrajnosti. Eksperiment z izrazili onkraj literarne govorice, jezika in klasičnih tiskanih medijev se je srečeval s prenosom ustvarjalne poiesis iz umetnostnega polja v okolje in življenje. Odpoved antropocentričnemu osmišljanju sveta $s$ tekstom ter pozornost do bivajočega $\mathrm{v}$ njegovi pojavnosti, neodvisni od subjekta, sta se znašli v soseščini strukturalističnih hibridov literature, teorije in avantgardnih manifestov. Vnašanje vizualnih senzacij, prvin tujih jezikov in marginalnih sociolektov v pesmi, drame in prozo je razsrediščilo sakrosanktno knjižno slovenščino kot steber narodne književne ustanove. Na drugi strani se je literatura politizirala, kritizirala potrošništvo, socialne krivice ter razkol med proklamiranimi ideali in dejanskostjo. Izzivanje kanona, večinske morale (tako katoliške kakor socialistično-humanistične) in uradne ideologije je spremljalo osvobojeno seksualnost, individualizem in brezmejno igro z jezikovno-umetniškimi kodi. Neoavantgardne struje, navdihnjene s teorijami in umetniškimi praksami iz zahodnih metropol, so se tudi v socialistični Sloveniji porajale kot rezultat sinkretizma, značilnega za kombiniran, pospešen literarni razvoj.

Med neoavantgardnimi oblikami šestdesetih in zgodnjih sedemdesetih let, kot so konkretna in vizualna poezija, eksperimentalno gledališče, novi roman ali politična metafikcija, je izstopal intermedijski konceptualizem skupine OHO (1966-1971; prim. Zabel idr.). V njihovem delu je miselni koncept postal podlaga za performans, readymade izdelke, konkretno in reistično poezijo, risbe, stripe, land-art in življenje v komuni. OHO je s svojim pristopom, ki je središčnost človeka zamenjal $s$ katalogiziranjem sveta stvari in narave, značilen pojav pospešenega razvoja $\mathrm{v}$ eni izmed socialističnih periferij umetnostnega sistema. Odlično informirani umetniki te skupine so se ažurno navezali na aktualne idejno-umetniške tendence po svetu in teoretsko dognali njihove potenciale. Cepili so jih na drugačno družbenopolitično okolje (tudi tu je umetnost prav tako postala izpostavljena poblagovljenju in potrošništvu) in kombinirali z repertoarjem, na razpolago doma - med drugim na heideggerjansko filozofijo reizma, kakršno sta uvajala Dušan Pirjevec in Taras Kermauner, pa tudi na zgodnje slovenske prilastitve strukturalistične teorije. OHO-jev sinkretizem je proizvedel inovacijo v svetovnem merilu. Opažena je bila drugod po Jugoslaviji, ${ }^{17}$ leta 1970 pa je doživela še konsekracijo v globalni metropoli. OHO je bil uvrščen

doživi revival, čeprav v omejenem obsegu (134-136). Tedanja kritika je modernizem sprejela ne samo kot legitimen tok, ampak celo kot vrednostno merilo.

${ }^{17} \mathrm{OHO}$ so spremljali in z njim sodelovali jugoslovanski neoavantgardni krogi, zlasti t. i. novosadski tekstualizem (prim. Dražić). 
$\mathrm{v}$ pregledno razstavo svetovnih neoavantgard $\mathrm{v}$ Muzeju moderne umetnosti v New Yorku. Milenko Matanović, David George Nez, Andraž Šalamun, Tomaž Šalamun in Naško Križnar so se predstavili v družbi umetnikov, kot so Sol LeWitt, Barry Flanagan, Joseph Beuys ali Yoko Ono (gl. McShine 77, 98-102, 197).

Prek navezav na sodobno strukturalistično teorijo sta se v slovenski književnosti oblikovali dve struji, imenovani ludizem in lingvizem. Ludizem, ki se 1966 začenja s Pokrom Tomaža Šalamuna, je ime za prestopniško igro s kodi nacionalne literarne institucije in sodobnega družbenega diskurza. Literarni karneval ludizma je dvojnik karnevalizacije, ki je spremljala protestno kulturo v dolgem letu '68 in jo še danes. ${ }^{18}$ Ludistično izzivanje tradicije, meščanskega estetskega okusa in komunistične oblasti $\mathrm{v}$ šestdesetih in zgodnjih sedemdesetih doživi vrh v pesmih Milana Jesiha, Vojina Kovača - Chubbyja in Iva Svetine. Njegovo Slovensko apokalipso je leta 1968 vzela na piko že omenjena izjava varuhov socialističnega humanizma.

Tako kakor v pariškem Tel Quelu ali Situacionistični internacionali je tudi v socialistični Sloveniji opazno stremljenje, da bi prek revolucionarne transformacije leposlovja $\mathrm{v}$ smer anarhoidne, subverzivne tekstualnosti revolucionarno transformirali družbene odnose. 18. marca 1968, nekaj mesecev pred zborovanjem v Študentskem naselju, je Tribuna natisnila Sollersov "Program $"{ }^{19}$ Ta manifest Tel Quela spaja teorijo z literaturo, ki se zaveda svoje zgodovine in prostora delovanja. V tem se neoavantargarda zavestno loči od zgodovinske predhodnice. ${ }^{20}$ Teorija in tisto, kar je označeval preživeli meščanski ideologem leposlovja, se hibridno križata $\mathrm{v}$ "praksi pisanja«: »Teorija tekstualnega pisanja se ustvarja v gibanju prakse tega pisanja" (Sollers, "Program»). Pisanje v pojmovanju Tel Quela se sklicuje na "tekstualni prelom « ekscesne protitradicije (Sade, Lautréamont, Mallarmé, Artaud, Bataille) ter na Marxa, Freuda in Nietzscheja (na idejo navdihujoče "monumentalne zgodovine"). Pisanje prelamlja $s$ "fetišizacijo" avtorja in umetniškega dela, kakor tudi z izpovednostjo in mimetičnostjo književnosti;

${ }^{18}$ To je, ugotavlja Tucker Sorenson, realizacija prej omenjenih metafor »cirkusa« in »razkroja» iz diskurza varuhov obstoječega.

19 „Programme« je Sollers objavil v Tel Quel 31 (jesen 1967).

${ }^{20} \mathrm{Na}$ to opozarja Sollers: „O tem [vprašanju o pisavi kot 'multidimenzionalni' problematiki, op. M. J.] že sto let pričajo vsi poskusi 'avantgarde', toda najpogosteje čisto spektakularno in celo regresivno, brez teoretske zavesti o tem procesu (primeri: italijanski fašistični futurizem, surrealizem, ki se potaplja v pomehkuženem okultizmu, psevdo orientalno poneumljanje sodobnih ameriških iskanj) «(Sollers, "Pisava» 19; poudaril M. J.). 
obrača se vase, se igra z jezikom, ga preoblikuje, pri tem pa proizvaja svojo teorijo: "Teorija označuje radikalno nonekspresivnost tekstualnega pisanja, njegovo nestalno igro, plurilinearnost, njegovo funkcijo 'ntegrativnega', aktivnega in produktivnega spoznavanja 'stvarnega' « (Sollers, »Program« 13).

1. aprila istega leta je Tribuna objavila prevod Sollersove polemike, ${ }^{21}$ ki telquelovsko koncepcijo pisanja pojasnjuje v kontekstu novega romana, ruskega formalizma, praškega strukturalizma in Derridajeve "gramatologije«. V luči Blanchotovega mota o nujni revolucionarnosti pisateljevanja izpostavi transformativnost tekstov, ki se upirajo ekspresivno-reprezentacijski estetiki: "'Revolucionarno' frazeologijo lahko vsakdo predlaga. Toda sodelovati v revoluciji misli, ki se piše, vedoč, da sta pisanje in revolucija homologna $v$ tem, da prevajata 'nemo' transformativno silo, to je veliko težje, to zahteva neko količino dešifracije in nenehno dešifrirajočo produkcijo " (Sollers, "Refleks" 21; poudaril M. J.). Decembra 1968 je v Tribuni izšel še prevod Sollersovega eseja, ${ }^{22}$ ki trdi, da je pisanje kot modernistično-tekstualistična alternativa literarnemu delu "funkcija družbene transformacije» (Sollers, "Pisava«). Pisanje, pojmovano s poststrukturalistično teorijo znaka, je Sollersu "translingvistični produkcijski proces«, medtem ko "smisel« $\mathrm{v}$ diskurzu zanj igra vlogo, »kot jo ima denar v cirkulaciji blaga«. Pisanje torej proizvaja smisel prek ekonomije označevalca; Sollers v njem vidi revolucionarni poseg v vladajočo ideologijo: "Priča smo skrajno silovitemu teoretskemu preobratu, transformaciji, katere posledice [...] bojo povzročile, da se pomete z določenim številom mitologij» (Sollers, »Pisava« 19).

Predstava o revolucionarnosti teksta, ki so jo $\mathrm{v}$ kapitalističnem Parizu zagovarjali pri Tel Quelu, se je 1968 dotaknila intelektualcev iz vrst ljubljanskih študentov. Tako je Dimitrij Rupel podpisal »Manifest: Nova smer v slovenski književnosti - protestno pisanje, politična književnost, proletarska kultura«, ilustriran s Pogačnikovo risbo topa in natisnjen v soseščini z manifestom Marka Švabiča, ki zahteva uvedbo proletkulta. Rupel frazeologijo eksistencializma in neomarksizma ${ }^{23}$

${ }^{21}$ Sollersov "Le réflexe de réduction« je izšel najprej v Quinzaine Littéraire (15. 1. 1968), nato pa še v Tel Quelovem zborniku Théorie d'ensemble v Parizu leta 1968.

${ }^{22}$ Sollersov esej "L'écriture fonction de transformation sociale « je izšel v Tel Quelovem zborniku Théorie d'ensemble v Parizu leta 1968.

${ }^{23}$ Npr.: „Svet se mi kaže kot svet politike, človek kot družbeno bitje, ki sleherni svoj korak usmerja v družbo, se v njej realizira in v njej doživlja svoj eksistencialni poraz« (Rupel 11). 
eklektično meša z navedki in prepisi iz Sollersa (»Pisava«). ${ }^{24}$ Politizacijo literature prek tekstualne prakse mladi Rupel v svoji krpanki razglasi za orožje proletariata $\mathrm{v}$ razrednem boju $\mathrm{z}$ buržoazijo, pomeni mu sredstvo za transformacijo družbe: ${ }^{25}$

1. [...] S pisanjem je treba razkrinkavati tihe tokove v političnem življenju, raztrositi politično misel in politični pomislek, da postaneta proletarska last. Z zavestjo, da se mora družba nenehno presnavljati, revolucionirati, se vključujemo v revolucionarno delovanje, ki ga vršijo komunisti v SFRJ. Moj upor in moja zavezanost je na območju akcije proletariata. [...]

3. Pisanje je nadaljevanje vojne $\mathrm{z}$ drugačnimi sredstvi.

4. Pisava je funkcija socialne transformacije sleherne produkcije, tako zanj konec razredne kulture pomeni konec sleherne kulture [...] (Sollers). [...]

9. Če govorimo o neznosnih odnosih v naši družbi, ne smemo imeti v mislih samo materialno bedo. Neznosna je hipokrizija, idolatrija, hierarhična kontrola, blagovnost [...] Študentje niso lepilo za razpoke v obstoječem sistemu.

10. Subjekt revolucije je tisti, ki razbija obstoječe, ki se s svetom ne pomiri (Rupel 1968: 11).

Istega leta je Rastko Močnik, tedaj povezan z OHO-jem, v Katalogu objavil tekst, ki podobno kot Ruplov kliče k subverzivni poetičnosti pisanja. Princip pisanja kot orožja trockistične permanentne revolucije $^{26}$ Močnikov tekst tudi udejanja. Zapis »Revolucija je brez projekta» ima - kakor Ruplov - značaj manifesta, a je zasnovan kot hibrid teorije in vizualne poezije. V njem se izrazi, ki spominjajo na frankfurtsko kritično teorijo ter novolevičarsko-eksistencialistični in erotični pojmovnik (samomor, upor, identiteta, projekt, subverzija, samozadovoljevanje, ejakulacija), ${ }^{27}$ družijo s koncepti s prizvoki trockizma, anarhizma in samoupravljanja (permanentna revolucija, subverzija, pluralizem projektov). V soseščini zgolj nakazanega interesa za pojem subjekta (znamenj strukturalizma in psihoanalize tu še ni zaslediti) je poudarjen preplet revolucije in poetične govorice:

\footnotetext{
${ }^{24}$ Sollers kot strukturalistični leninist Sartra ni dobro prenašal, pri Ruplu pa njuna jezika udobno sobivata.

${ }^{25}$ Rupel se naslanja na francoski izvirnik.

${ }^{26}$ Lev Trocki je proletariatu določil poslanstvo nosilca svetovne revolucije, saj po njegovem socializem ne bi mogel obstati v eni sami državi. Trockizem je imel v šestdesetih letih ob maoizmu velik vpliv na študentsko gibanje Zahodne Evrope.

${ }^{27}$ Ti izrazi spominjajo na pesniške tekste Aleša Kermaunerja in Žižkove komentarje nanje (prim. Juvan, »Literature«).
} 
Revolucija

je permanentna

revolucija:

POETIČNA

SUBVERZIJA (Močnik 109)

V revolucionarnih šestdesetih in zgodnjih sedemdesetih letih avantgardnega statusa očitno ni zahtevala le literatura, pač pa tudi strukturalistična teorija. Slovenski teoretiki, na tekočem s sodobnim francoskim (post)strukturalizmom, so sprva spominjali na zavezništvo ruskih formalistov $s$ futurističnimi umetniki, sklenjeno v ozračju oktobrske revolucije. Preobrazba družbe je bila v dolgem letu '68 sprva skupen projekt političnih, literarnih in teoretičnih avantgard; delile so si tudi medije, na primer Tribuno in Probleme. Do leta 1975 pa so Slavoj Žižek, Rastko Močnik, Braco Rotar in drugi lacanovski semiotiki pretrgali z literaturo, se predstavili kot edina pristna avantgarda in se $s$ Problemi - Razpravami odcepili od skupne periodike. Teoretska kritika nacionalne književne institucije zdaj ni prizanesla niti sočasnemu literarnemu modernizmu, ki je po samoukinitvi $\mathrm{OHO}$-ja po mnenju lacanovcev nazadoval in se vračal $\mathrm{k}$ prežitkom meščanske oziroma malomeščanske ideologije (prim. Juvan, „Literary«). Lacanovska zavrnitev revolucionarnega romantizma slovenskega modernizma spominja na omenjeni leninistični odnos Tel Quela do študentskega gibanja. Nikola Dedić (»On Yugoslav«) je podčrtal, da so bili slovenski poststrukturalisti po eni strani izjemni v socialističnem taboru, ker so se brez težav seznanili s francosko teorijo. Samoupravni socializem v Jugoslaviji je očitno dopustil revizijo samega marksizma iz perspektive, ki bi jo v Vzhodni Evropi obsodili kot formalistično. Po drugi strani je teorija kroga Problemov - Razprav s svojim specifičnim sinkretizmom izoblikovala inovativni periferni kompromis, ki je zaradi dosledne izpeljave Lacanove psihoanalize na področju historično-materialistične kritike ideologije sčasoma postal osrednja referenca globalizirane teorije.

Kakšna je bila po poskusu svetovne revolucije usoda modernizma v socializmu, kaže razvoj slovenskega literarnega toka, ki ga je Taras Kermauner imenoval lingvizem. Tako kot ludizem izvira v poznih šestdesetih letih in sega vse do postmodernizma osemdesetih let. Oprl se je na teorijo teksta Rolanda Barthesa, Jacquesa Derridaja, Julie Kristeve in Sollersa. Besedilo je obravnaval kot medbesedilno strukturo, katere pomen se širi po verigi označevalcev. V nasprotju z ludizmom, ki je karnevalizacijo uporabil za parodiranje romantične tradicije, komunistične ideologije in katoliške morale, je lingvizem Nika Grafenauerja in Borisa A. Novaka odstopil od političnih referenc. Njegov samorefleksivni 
pogled se je osredotočil na prizorišče pisanja in bistvo lirike. V pridušitvi afektov nasprotovanja, značilni za lingvizem, lahko razberemo simptom »imunizacije» (prim. Esposito 65-106). Od sredine sedemdesetih let je imunizacija modernizma v lingvizmu odražala razpoloženje po izteku dolgega leta 1968, ko se je zdelo, da je čas revolucij morda za vedno minil. Izhajala je iz umika $v$ depolitizirani esteticizem in individualnost v obdobju t. i. svinčenih sedemdesetih let, ko je Titov režim taktično pomiril študentsko gibanje in mu v marsičem ugodil, obenem pa zatrl liberalne in nacionalistične težnje $\mathrm{v}$ jugoslovanskih republikah. $\mathrm{V}$ osemdesetih letih sta sledila uničujoča dolžniška kriza Jugoslavije in njen razpad, podžgan s povampirjenim nacionalizmom.

\section{Od maja '68 do novembra ' 89}

Proces med 1968 in 1989 razlagata dve nasprotujoči si interpretaciji. Prva temelji na inverzijah, druga - manj vplivna - pa odkriva kontinuitete. Zagovorniki današnjega neoliberalnega reda, kakršen je Vladimir Tismăneanu (Promises), običajno govorijo o koncu progresivnih velikih pripovedi, za katere menijo, da že v sebi nosijo kali spodletelosti. Takšne razlage napovejo konec zgodovine $\mathrm{v}$ trenutku, ko sta prosta trgovina in liberalna demokracija, potem ko sta razbili ekonomsko neučinkovit in socialno inerten vzhodni "totalitarizem", začeli vladati planetu. Kristin Ross (May '68), avtorica monografije o "posmrtnem življenju maja 68«, in drugi nasprotniki apologetov današnjega statusa quo pa obžalujejo, da je emancipacijski potencial revolte neoliberalni svetovni red pacificiral in sistematično pozabil.

Res, leto '89 je videti kot zrcalna slika leta '68. Zrcalijo se ne samo desetici in enici obeh letnic. Dogodki, procesi in ideologije prav tako kažejo preobrate. Ikonično postavljanje barikad v Parizu je nadomestil emblematičen padec berlinskega zidu. Nekdanji radikalni ideologi so se spremenili v nove filozofe, medtem ko so se revolucionarni yippiji preobrazili v yuppije, zagledane $\mathrm{v}$ svoj biznis. Nekdanji borci proti establišmentu so bili rekrutirani v nacionalne ali nadnacionalne politične elite. Namesto naprednega internacionalizma smo priča retrogradnemu nacionalizmu in populizmu, medtem ko je antikapitalizem moral prepustiti prostor čaščenju kapitalizma kot naravnega stanja sveta. Namesto da bi participirali v nacionalni in mednarodni politiki in jo poskušali spremeniti, perverzno uživamo $\mathrm{v}$ spektaklu političnega razreda, ki se je ponižal v populistične zabavljače, lutke v rokah globalnega kapitala. 
Na splošno se zdi, da je zgodovinska konjunktura leta 1968, katere boj za preoblikovanje sveta je doživel poraz, privedla do leta 1989, ki pa je svet vendarle spremenilo, a tako, da je oznanilo konec utopije upora, starejšega le dve desetletji. Postmoderni neoliberalizem, ki se je pretvarjal, da je izpolnil zahteve študentov po individualnih svoboščinah in sprostitvi togih hierarhij, je razglasil zmago nad komunističnim totalitarizmom, spodbudil gospodarsko rast s prilagodljivimi, lateralnimi načini globalizirane proizvodnje ter razširil diskurz o človekovih pravicah in kulturnih identitetah po vsem planetu. Zdi se, da je ta svetovni red v kali zatrl vsako alternativo, ki bi lahko črpala navdih iz spomina na maj '68.

Kljub temu so Giovanni Arrighi, Terence K. Hopkins in Wallerstein (»1989«; "1968«) pokazali, da je prav tako utemeljeno razumeti leto 1989 kot nadaljevanje leta 1968, "vaje« svetovne revolucije. Prepoznavajo nadaljevanje nedokončanega projekta, ki so ga začele protisistemske sile zunaj institucionalne stare levice. Spontano vznikla gibanja postindustrijskega delavskega razreda in nove inteligence, ki so $\mathrm{v}$ šestdesetih letih prejšnjega stoletja "vadila" boj proti asimetrijam svetovnega-sistema, nadaljujejo svoj spopad tudi okrog leta 1989, a v kontekstu pomembne zgodovinske spremembe: propada sovjetskega socializma, zatona zahodne socialne države in premoči globaliziranih financ nad politikami nacionalnih držav. $\mathrm{V}$ tem kontekstu sta svojo koncepcijo multitude kot alternative svetovnemu kapitalističnemu imperiju vpeljala tudi Negri in Hardt.

Že mogoče, da sta po zatonu modernizma in študentsko-delavskega uporništva postmodernizem $\mathrm{v}$ estetiki in neokonservativizem $\mathrm{v}$ politiki osvojila vodilne sile svetovnega-sistema. Podobno je v Sloveniji in drugih jugoslovanskih republikah zadnji sezoni modernizma sledila kriza socialističnega samoupravljanja, krvavi razpad federacije in nastanek držav naslednic, ki jih v obdobju tranzicije svetovni-sistem požira drugo za drugo. Po drugi strani pa civilna družba osemdesetih let $s$ svojimi ekološkimi, feminističnimi, LGBT, antirasističnimi in drugimi gibanji ne bi bila mogoča brez "vaje« iz dolgega leta 68. Prav tako ne bi mogli biti priča množičnim antiglobalističnim gibanjem novega tisočletja, na primer "Occupy Wall Street«. V kontrakulturi je pank že v sedemdesetih letih z namerno grobo energijo izostril sporočila bolj blagozvočnega uporništva rokerjev. $\mathrm{Na}$ področju kulturne produkcije so bile post-avantgarde, kakršna je Neue Slowenische Kunst, neposreden odgovor na konceptualni in politični radikalizem njihovih neoavantgardnih predhodnikov, kakršen je bil OHO. In končno ne more biti dvoma, da kritična teorija, s katero lacanovska "trojka" iz Ljubljane danes po svetovnih metropolah presoja globalna politična vprašanja, izhaja iz obrobnega intelektualnega laboratorija šestdesetih let. 


\section{LITERATURA}

Anderson, Perry. "Modernity and Revolution«. New Left Review 1.144 (1984): 96-113.

Arrighi, Giovanni, idr. »1989, the Continuation of 1968«. Review 15.2 (1992): 221-242.

Arrighi, Giovanni, Terence Hopkins in Immanuel Wallerstein. »1968: The Great Rehearsal«. Antisystemic Movements. London: Verso, 1989. 97-118.

Baškovič, Ciril, Pavel Gantar, Marjan Pungartnik in Pavel Zgaga. Študentsko gibanje: 1968-72. Ljubljana: Republiška konferenca ZSMS, 1982.

Baudry, Jean-Louis, idr. "La Révolution ici maintenant«. Tel Quel 34 (1968): 3-4.

Bray, Joe, idr., ur. The Routledge Companion to Experimental Literature. London; New York: Routledge, 2015.

Casanova, Pascale. La République mondiale des Lettres. Paris: Seuil, 1999.

Combes, Patrick. Mai 68, les écrivains, la littérature. Paris: L'Harmattan, 2008.

Čepič, Zdenko. „Burno leto 1968. Politična sprostitev. Zaton partijskega liberalizma«. Slovenska novejša zgodovina. 2. Ur. Jasna Fischer idr. Ljubljana: Mladinska knjiga, 2005. 1054-66, 1069-75.

Debord, Guy. Družba spektakla; Komentarji k družbi spektakla; Panegirik. Prev. Meta Štular, Tanja Lesničar Pučko. Ljubljana: ŠOU, Študentska založba, 1999.

Debord, Guy. »Thèses sur la revolution culturelle«. Internationale situationniste 1 (1958): $20-21$.

Deckard, Sharae, idr. (WReC). Combined and Uneven Development: Towards a New Theory of World-Literature. Liverpool: Liverpool University Press, 2015.

Dedić, Nikola. »On Yugoslav Poststructuralism: Introduction to 'Art, Society/Text' «. ARTMargins 5.3 (2016): 93-101.

D'haen, Theo. "Major Histories, Minor Literatures, and World Authors«. CLCWeb: Comparative Literature and Culture 15.5 (2013). Splet. <http://dx.doi. org/10.7771/1481-4374.2342>

Dolgan, Marjan, ur. Slovenski literarni programi in manifesti. Ljubljana: Mladinska knjiga, 1990.

Dražić, Silvia. Novosadski tekstualizam. Novi Sad: Edicija Kontrateg, 2018.

Ďurišin, Dionýz. Čo je svetová literatúra? Bratislava: Vydavatel'stvo Obzor, 1992.

Esposito, Roberto. Bios: biopolitika in filozofija. Prev. Mojca Mihelič in Boštjan Nedoh. Ljubljana: Založba ZRC SAZU, 2015.

Fichter, Madigan. »Yugoslav Protest: Student Rebellion in Belgrade, Zagreb and Sarajevo 1968«. Slavic Review 75 (2016): 99-121.

Foster, Hal. The Return of the Real: The Avant-Garde at the End of the Century. Cambridge, London: MIT Press, 1996.

Friedman, Susan Stanford. Planetary Modernisms: Provocations on Modernity across Time. New York: Columbia UP, 2015.

Gabrič, Aleš. "Intelektualci kot opozicija. Približevanje kulturnih dobrin širšemu krogu ljudi. Obračun s kulturniško opozicijo. Sproščena šestdeseta leta v kulturi. Intelektualci v primežu 'svinčenih let'. Med modernizmom in postmodernizmom. Popularna kultura«. Slovenska novejša zgodovina. 2. Ur. Jasna Fischer idr. Ljubljana: Mladinska knjiga, 2005. 1024-35, 1056-69, 1125-27, 1139-43.

Giddens, Anthony. The Consequences of Modernity. Cambridge: Polity Press, 1990.

Gobille, Boris. Le Mai 68 des écrivains: Crise politique et avan-gardes littéraires. Paris: CNRS éditions, 2018.

Hardt, Michael, in Antonio Negri. Multitude: War and Democracy in the Age of Empire. New York: The Penguin Press, 2004. 
Hecken, Thomas, in Agata Grzenia. »Situationism«. 1968 in Europe: A History of Protest and Activism, 1956-1977. Ur. Martin Klimke in Joachim Scharloth. New York: Palgrave Macmillan, 2008. 23-32.

Jameson, Fredric. A Singular Modernity. London: Verso, 2002.

Juvan, Marko. "Literature, theory and politics of the long '68: the last season of modernism and peripherality". European review (2020). Splet. DOI: $10.1017 /$ S1062798720000848.

Juvan, Marko. »Peripheral Modernism and the World-System: Slovenian Literature and Theory of the Nineteen-Sixties«. Slavica Tergestina 23.2 (2019): 168-199.

Kanzleiter, Boris. »Yugoslavia«. 1968 in Europe: A History of Protest and Activism, 19561977. Ur. Martin Klimke in Joachim Scharloth. New York: Palgrave Macmillan, 2008. 219-228.

Klasić, Hrvoje. Jugoslavija in svet leta 1968. Prev. Višnja Fičor in Seta Knop. Ljubljana: Beletrina, 2015.

Knabb, Ken, ur. Situationist International Anthology. Revised and expanded edition. Berkeley: Bureau of Public Secrets, 2007.

McShine, Kynaston L., ur. Information: Summer 1970. New York: The Museum of Modern Art, 1970.

Močnik, Rastko. [»Revolucija je brez projekta»]. Problemi 6.67-68 (1968) = Katalog: 107-109.

Mohandesi, Salar, idr. "What Was 1968?«. Voices of 1968: Documents from the Global North. London: Pluto Press, 2018. 1-34.

Moretti, Franco. Grafi, zemljevidi, drevesa in drugi spisi o svetovni literaturi. Ur. in prev. Jernej Habjan. Ljubljana: Studia humanitatis, 2011.

Neubauer, John in Marcel Cornis-Pope. »1956/1968: Revolt, Suppression, and Liberalization in Post-Stalinist East-Central Europe«. History of the Literary Cultures of East-Central Europe: Junctures and Disjunctures in the 19th and 20th Centuries. 1. Ur. Marcel Cornis-Pope in John Neubauer. Amsterdam, Philadelphia: John Benjamins Publishing Company, 2004. 82-105.

Rabaté, Jean-Michel. The Future of Theory. Oxford: Blackwell, 2002.

Ross, Kristin. May '68 and Its Afterlives. Chicago: University of Chicago Press, 2002.

Rupel, Dimitrij. "Manifest: Nova smer v slovenski književnosti - protestno pisanje, politična književnost, proletarska kultura«. Tribuna (9. 10. 1968): 11.

Škulj, Jola. »Moderna in modernizem«. Primerjalna književnost 32.1 (2009): 89-106.

Sollers, Philippe. »Pisava kot funkcija družbene transformacije«. Prev. Sonja Balent. Tribuna (4. 12. 1968): 19.

Sollers, Philippe. »Program«. Prev. Vojislav Likar. Tribuna (18. 3. 1968): 13.

Sollers, Philippe. "Refleks redukcije«. Tribuna (1. 4. 1968): 21.

Stierli, Martino, idr. Toward a Concrete Utopia: Architecture in Yugoslavia, 1948-1980. New York, N.Y: The Museum Of Modern Art, 2018.

Šuvaković, Miško. Anatomija angelov: Razprave o umetnosti in teoriji v Sloveniji po letu 1960. Prev. Vlasta Vičič. Ljubljana: Znanstveno in publicistično središče, 2001.

Tel Quel. »Mai 1968«. Tel Quel 34 (1968): 94-95.

Terian, Andrei. "Socialist modernism as compromise«. Primerjalna književnost 42.1 (2019): 133-147.

Tismăneanu, Vladimir, ur. Promises of 1968: Crisis, illusion, and utopia. Budapest: Central European University Press, 2011.

Tötösy de Zepetnek, Steven. »Configurations of Postcoloniality and National Identity: In-between Peripherality and Narratives of Change«. The Comparatist: Journal of the Southern Comparative Literature Association 23 (1999): 89-110. 
Tucker Sorenson, Kaitlyn. "Radikalna igra: ljubljanska alternativa leta 1968«. Prev. Andrej Zavrl. Rokopis. 2020.

Vinen, Robert. The Long '68: Radical Protest and Its Enemies. London: Allen Lane, 2018.

Wallerstein, Immanuel. »Antisystemic Movements, Yesterday and Today«. Journal of World-Systems Research 20.2 (2014): 158-172.

Zabel, Igor, idr. Oho: Retrospektiva $=$ eine Retrospektive $=$ a Retrospective. Ljubljana: Moderna galerija Ljubljana, 1994.

Žižek, Slavoj. "Introduction: The Spectre of Ideology«. Mapping Ideology. Ur. Slavoj Žižek. London: Verso, 1994. 1-33.

\section{The Fate of May '68 and (Post-)Socialism: Literature Between Revolution and Transition}

Keywords: literature and society / student movement / revolution / socialism / modernism / neo-avant-garde / world-system / Slovenian literature

Based on the idea that "the imaginative proximity of social revolution" (Anderson) is decisive for modernism, the article discusses the neo-avant-garde radicalization of modernism in the 1960s and 1970s from the perspective of world-systems theory. The author focuses on the literary and theoretical field of capitalist France in comparison with the accelerated development of both fields in the socialist periphery of global modernism-in non-aligned Yugoslavia and its system of socialist self-management. The article interprets the connection between experimental literature and (post-)structuralist theory in Slovenia during "the long 1968". It developed from the original neo-avantgarde alliance to the split in the mid-1970s. Finally, the author presents different interpretations of the historical process between the attempted student revolution of 1968 and 1989, when globalized capitalism seized power over socialism and postmodernism entered modernism.

1.01 Izvirni znanstveni članek / Original scientific article

UDK 82.02"1968/1989"

930.85(437.12)"1968/1989"

DOI: https://doi.org/10.3986/pkn.v43.i3.01 